\title{
An Essay on The Debate About Who Should Rule.
}

\author{
Somchai Saenphumi ${ }^{1}$, Worachet Tho-un ${ }^{2}$ \\ ${ }^{1}$ Mahamakut Buddhist University, ${ }^{2}$ Mahamakut Buddhist University \\ Email: ${ }^{1}$ Somchai.sa@mbu.ac.th, ${ }^{2}$ worachet.th@mbu.ac.th.
}

\begin{abstract}
This article on the debate about who should rule? It discusses the diverse answers of influential political philosophers and political scientists. The study found that Plato argues that philosopher king should be the ruler. In contrast, people cannot take part in the Government. Rousseau supports the rule by the people who must be able to legislate.

Furthermore, try to enforce it on yourself before leading to a majority vote. Aristotle believed that no one or any other group was a ruler but ruling it for the public good. While Mill believed that the representative system could create great happiness for the people, and it can be recalled. Finally, Sylvan argues that there was no need for a ruler. Because rulers bring war and exploitation, people can rely on themselves without their ruler to aim for utopia or an ideal society that should be inhabited. As a result, the representative system of the authors' view is the most appropriate form today. Because when a ruler is a tyrant, we can always recall power and choose a new ruler and create great happiness for people as well as possible.
\end{abstract}

Keywords

ruler, Government, representative, political philosophy.

Article Received: 10 August 2020, Revised: 25 October 2020, Accepted: 18 November 2020

\section{Introduction}

A debatable about who should rule? It has been a great question in political philosophers from ancient Greece to the present. Nowadays, the rule's mainstream is often related to the liberal democratic ideology under a representative system. However, the idea was challenged by conservative ideologies. In particular, the phenomenon of right-wing leadership in the United States or the emergence of anarchist groups rejects states and rulers.

For this reason, the authors are interested in studying and comparing the ideas of influential political philosophers and political scientists on the debate. For readers to know the answers about the various good rulers. Moreover, what criteria must be used for consideration? Within this article, the authors will lead the reader to the sage's answer to the above question: Who should be a ruler? Starting with Plato, Rousseau, Aristotle, Mill, and Sylvan, each with a view to who should be. What kind of ruler are they similar to or different? Readers will find the answer in this article.

\section{Plato's answer was, "Ruling should come from the selection. Not anyone"}

In response to this first reply, the authors take the great philosopher who softened ancient political studies and influenced modern city study. The readers, especially the classical political philosophy, might have guessed that the authors were referring to the wise man, Plato, who wrote The Republic, who attempted to explain ancient times political politics through "Dialogue." Behind this book is essential to modern political education and political science in Crito. Conversations within these two works, there are two characters: Plato himself. Moreover, his teacher is Socrates. As mentioned, these books are essential for the study of politics, political science. Those who are interested in this field need to read through to learn an example of questioning.
Moreover, raven tries to answer questions in political philosophy, Especially issues of who should be the ruler? Within the content of this Plato work, the authors were aware of Plato's attitude towards (ancient) democratic Government. Plato strongly opposed the idea. Because ancient democracy is a direct form of Government to understand ancient democracy and understand Plato, the authors want to explain the form of democracy in the citystate of Athens.

The city-state of Athens is one of the Greek city-states. In the history of world politics, Athens used democracy as the first in the world. Athens is a small state with an area of approximately 2,500 square kilometers. Moreover, approximately 60,000 citizens (Athenian citizens do not include children, women, slaves, and aliens) [1, p. 55]. When compared to the present, the city-state of Athens is similar in size to Thailand's municipality. However, given Athens' size and space, direct democracy was possible. In other words, Athens direct democracy was all citizens of Athens's city-state participate in Government, particularly the right to attend public councils to decide on public matters, which does not have a representative system like today.

Nevertheless, this does not mean that all citizens attend the meeting. The Athenian system was how all citizens were rotated to serve in people's councils under a 'Draw lots' system. Anyone caught doing it. In Plato's work, it is said that at one point in the life of all citizens of Athens, there was at least one active duty. At this point, the authors see the drawing system as the most equal. Since everyone will never know if they will be caught in the act or not, everyone has equal citizenship, regardless of their qualifications such as economic status, occupation, and education, excluding sex, age, slavery, and foreigners. Athens citizenship is limited to male citizens aged one and over and must have an Athenian father [2, pp. 14-16] .It shows that Athenian democracy is a regime in which citizens directly participate in the majority of unqualified and qualified citizens. It was 
at this point that Plato came out to attack Athenian rule, not appropriate.

Plato has raised an exciting question about the ruler. Each human being is born with different aptitudes according to each individual's suitability, i.e., some people are skilled in engineering. In contrast, engineers cannot qualify for medical treatment. On the other hand, doctors were unable to build houses as engineering. From the above explanation, the authors found that Plato tried to propose logic so that everyone is born without equality. Everyone is born different, which is defined by a different nature here. Plato includes "Leadership or Ruler." Plato suggested that the ruler must have specific skills, unlike the average person or not someone like the Athenian regime .Plato's ideal ruler must be a natural guardian, have knowledge and skills, and receive good ruler training. Plato addressed the issue through his character Socrates in a metaphor dialogue Plato calls "Ship of State Analogy."

Ship of State described Plato's metaphor through seafaring and leading the state forward in a desirable direction. In which to lead the ship in the desired direction or reach that destination. Plato suggests it requires a captain with knowledge, navigation skills, wind direction, a view of the crew's stars, and rule. To bring the boat to the destination, and the captain must not be a crew or a slave. According to this logic, the state's rulers must know when considered the regime. And skills in the science of Government, not anyone. Plato used the metaphor of the ship of state to explain why philosophers should be king. Though he does not seek power, the navigator is the only one who can steer a proper course-much as the philosopher is the only one with the knowledge to rule justly [3, p. 38].

In other words, the ruler should be trained and be the right people. Through the educational screening system, Plato used the educational system as a tool for screening people. To classify people, Plato suggests that all children born at the age of 5be brought together and separated from the family. All children will be educated equally. At a particular time, they were put to the test. Such as a child old enough to take that first exam, anyone who fails the exam will be split into "The general public" to work in general, such as carpentry, merchants according to their expertise .Those who pass the exam will receive a higher level of education. Likewise, after a while, there will be a test. If anyone fails to pass this second test, they will be separated from the guardian to serve state security. He also served as a civil servant in various fields, while the rest had to be educated until the age of 50, so it was appropriate to be a ruler. Here, Plato uses the term "Philosopher King" [4, pp. 129-132, 5, pp. 67-68].

From Plato's proposal, the authors found that he had an attitude about the rule that should be the skill. This is no different from being a doctor or a ship captain who must be trained with appropriate skills. In this sense, Plato sees people as rulers as undesirable. Because they had not been trained very well, the people lacked the skills of governing Plato thinks that if people make public decisions on their inefficiency, they will have enormous consequences for the country. At this point, the authors viewed Plato as trying to propose the idea of natural dictatorship. With good people who know about drum distillation, Not anyone. In the sense of Plato, the authors viewed it as not a present-day dictator.
Instead, it is a dictator who has undergone building a leader with advanced governing skills.

Moreover, these people will have to give up their possessions. They do not have a wife and children because they might induce the philosopher king to act corruptly. However, the authors think that Plato's concept is challenging to put into practice. Because Plato's qualifying rulers had to dwell on books for more than 50years, they cannot have private property and family [5, p. 69]. Anyone or any organization can condone the philosopher king because Plato gave the philosopher king the most innocent. Alternatively, when the philosopher king's actions violated a minority of the kingdom. Will those minorities be protected?

\section{Jean Jacques Rousseau's answer was, "people are the best rulers."}

When we consider Plato's answer above, readers will find that Plato does not care about it and does not believe that people can become rulers. Plato's extremity led to the political-philosophical argument that "People are the best rulers." In political philosophy, many thinkers have suggested, especially Jean Jacques Rousseau. He proposed the opposite idea of Plato: insisting that people should be the ruler as possible. Rousseau offers this answer within his masterpiece, "The Social contract," where he explains that states were formed by accident and states were born to be bad states. Because a state in this sense only has a handful of beneficiaries.

Nevertheless, most people lose their benefit besides being oppressed when this human relations model arises from this coincidence causing human freedom and equality to be lost . From the original man in the community contract theory, that man has freedom in its natural state, are equal under bondage humans lose their freedom after the transfer of power to the rulers so that they come to protect the safety of life and property. [6, p. 181]

Rousseau suggested that the state emerged from the bad. However, it can be justified by reformatting power relations between people. The implication is that the political solution is to give all people the action to abolish the state that it once had. Because he views the state as a bad thing, Once canceled, everyone will come and make a new community contract. Because he sees that a good state must be a state in which people have freedom and equality. He proposes to create a model of Government where humans coexist. Able to protect and protect members and his property under typical power and ties. However, he also argued that a righteous form of Government with freedom and equality was the renewal of the community contract like the state form agreement, which he believes is the legitimated form of Government [5, p. 80].

Rousseau's good regime suggested that all citizens could propose laws on their own. It reflects that everyone has equal rights and freedoms because everyone can legislate on their own. Then apply the law that you created and apply it to yourself, as if everyone had freedom in the case of the majority vote on proposed legislation that we have not been received from the majority. Our proposed law has fallen. Even if we assume that the laws that we offer are suitable for everyone or the state, it was not. Because it is only suitable for the proponents .However, Rousseau explains 
that although the majority does not approve of the laws proposed by the public. However, while voting, we have no idea what the outcome will be. [4, pp. 140-142]

The authors believe that Rousseau tried to argue that the parent is the best protection. Under the reason that If we want a form of Government that rightfully is freedom. Moreover, equality: We must make the people their ruler because the legislation itself is a tool to guarantee people's freedom and peace. He proposed that people have the power to legislate. Moreover, the Government or the executive is just the person who adopted the public resolution, or the Government is merely obeying the orders of the people contrast to Plato, the ruler must be the right person with skills through practice making people unable to be a ruler. However, the ideas of Rousseau, if adopted, may present a problem. Due to a large number of people, it is not easy to hold meetings simultaneously. However, Rousseau's qualities have resulted in our righteousness values that the people must agree upon. And Rousseau's influence on the French Revolution of 1789.

\section{Aristotle's answer was: "Anyone can be a ruler, but please do it for the public."}

In this third answer, the authors will lead the reader to find the answer that "Anyone can be a ruler. However, let us do it for the public good." That is regardless of the regime. Just ask to rule for the benefit of the public or for the people who proposed this answer was Aristotle. He was a student of Plato. Who believes in being a philosopher king, Aristotle presented ruler issues through his famous book important to studying politics and political science, "Politics" in volume III. He began to explain within the book by classifying the pure form of the state's political community. Under the tripartite classification, Aristotle began by explaining that his criteria could be divided into two criteria: [7, pp. 11831185]

The first criterion is that the number of people using political power that Aristotle is seen as holding power is different. Moreover, it can be classified into sub-groups that can be divided into three groups: The One (Rule by a Single Person) or dominion of a single person. The Few (Rule by a select Few) or dominion is in the group, and the many (rule by the many), or the dominion at the mass [7, p. 1185]. From Aristotle's point of view, whether it is a form of Government can only be classified into three summary formats. However, the classification of power is not enough as good or bad because this criterion only describes the form of the regime. So, he proposed the second criterion to bridge good and bad gaps.

The last criterion is the enumeration of the parenting model in conjunction with the first criterion, under the goal of exercising power to govern. That is, when the ruler, whether one person, a group of people, or the public, has power in that hand. May use such power for personal gain or the public interest, and when any form of governing uses power for personal or group, Aristotle called the regime "bad" forms part of the governing authority for the common good or the public interest. Aristotle called it a "good" round. When both criteria are taken into account and combined, there are three traditional forms of Government: power on one person, power on a group of people. Moreover, power is at the public. When considering the goals of exercising power into consideration [3, p. 43].

First, the one is a form of governing body in which only one person dominates. If power is used for the common good, it is called monarchy. This kind of exercise of power is often found in countries with a monarchy or absolute monarchy. Where power is centralized in one person and is used primarily for the majority of people. However, when one person's power is used to benefit himself or for that group, Aristotle is called tyranny. Second, the few is a form of Government by a small number. If the power used for public interest or benefit of the public, Aristotle called aristocracy, but if a group of people forms a governing authority to benefit a person or group of dissenters, Aristotle called oligarchy. Third, the many is a form of Government or majority. If the mass uses power for the public good or the benefit of the public, Aristotle is called Polity. Nevertheless, if the mass form of Government uses power for themselves, Aristotle calls it democracy.

The authors found that Aristotle divided form of government targets and power; if the power to the public's interest, it is a good regime. Furthermore, if the Government used for personal or group, it will be a bad rule. We will see what Aristotle proposed that. He does not care what power is in the hands of anyone or any group of people. Instead, he points to the use of power, whether it was for the public or the self.

Nevertheless, in the case of the public's power, how do we know if power is used for good or bad since most people's needs are also in the public's interests? On this point, Aristotle explains that the majority of the public governing for the public means that the use of Government for the common benefit of the advancement of the state. It is not an exercise of power for the public's needs, but the state retreats i.e., suppose the mass has the power to legislate on taxation and see that tax collection is the burden of the majority of the state's citizens. Therefore, the public has enacted laws so that people do not pay taxes, etc. These actions Aristotle regarded as made for the benefit of their people, ignoring the public interest. As a result, the state may step into the state fall, because of the operations of the state-required tax money from the public. Moreover, if the state has no tax from the people. The state cannot function in various affairs, so he sees power in that direction as bad and called democracy.

On the other hand, if the mass uses their power for the common good, which is different from the self-interest of the crowd i.e., if a state reduced some taxes to create more intra-state investments, incentivize merchants to increase their trading capabilities or with reasons for the state's progress. Using this power of governance by the mass, Aristotle called Polity or a governing form. The goals of using power to benefit the public as a form of rule by the public good. He uses this term because it is difficult to define the public's particular virtues under any name. Therefore, he uses the term above substitute for the form of Government in which the power in the public's hands and the public is right and moral for the public good [7, p. 1185].

From Aristotle's proposal, the authors found that he disagreed with his teacher on several issues. However, Aristotle and Plato agree that democracy is a form of mass 
government done in their interests but not for the public good. That model is ancient democracy, as the authors explain in Plato's answer because Plato believed that good rulers trained to practice their governing skills. Rousseau said that all people should be rulers, which is consistent with Aristotle only in mass government. Nevertheless, Aristotle believed that a ruler could have as many people as. Nevertheless, they must use their power for the public good, Especially the polity model.

\section{John Stuart Mill's answer was, "the people's representative is the best ruler. "}

Nowadays, we are familiar with the representation system. This system is a form of Government in which people can participate in presenting their representatives to legislate. Moreover, bring those laws into force. The form of Government is a Representative Democracy thinker for many forms of the democratic government model. One of them is John Stuart Mill. Mill's idea based on what concept? Which he based on from the Utilitarianism school .The core is about happiness or pleasure. It is this core that Mill sees as a good thing that does not depend on anything else. All human actions go on for happiness and avoid suffering, which led to the utility thinkers' fundamental beliefs adopted as a fundamental principle of society. It indicates that a good society is a society that adheres to the fundamental principles that Mill offers, Greatest Happiness for the Greatest Numbers [8, p. 57]. He argues that acceptance of utility is the foundation of happiness, which is the foundation of morality, that right action is the act that can bring about happiness. The wrong action is the act that has the opposite effect of happiness. Happiness without suffering, pain. It is a state of liberation from suffering that is the only desirable destination. Furthermore, there must be a way to be free from suffering. [4, pp. 154-155]

For Mill, the representative system is the only means by which democracy can survive in the modern world [5, p. 94]. Mill argues that advocating for surrogate Government is that public Government is practically impossible in large states. Therefore, need to have a representative government Mill sees surrogate Government as the best Government. As self-government is often problematic, other forms of Government are more appropriate for them. A representative will enable people to progress to the next stage of society. Mill believes in rule by specialists, but the supremacy comes from the people to take charge of the Government. If it cannot control, it may be a tyranny as well as an absolute monarchy. Besides, Mill suggests that councils are the body of thought, a fine example of intelligence at all levels. All of which have the right to participate in public affairs, whose mission is to express the people's needs and demands and discuss the opinions of the people. Mill believes in a balance of power between the Government and the people's representatives because if the people's representative organization has too much power, it will hinder the Government's work. Simultaneously, When the people's representative organization is too weak, they cannot control the Government. The organization it represents lacks the psychological qualities necessary to operate the evil vested interests. The strategy that brings people with knowledge and expertise to work is to build a bureaucracy. However, the bureaucracy often deteriorates to become a permanent job detracting from the trained government officials' individuality.

In voting, Mill argues that the simple majority will be dangerous and lead to evil regimes. He offers to educated or professional people. Alternatively, other classes can vote for more than one time. This proposal shows that Mill fears boundless democracy. He believes in the representative organization that consists of two main classes in society: the working class.

Furthermore, the elite was equally balanced. To hope that representatives of each class vote in line with their interests [9, pp. 216-219]. Thus, participation in politics and governance is a good and desirable thing. It can bring happiness and move towards the goals of everyone. Because Mill sees that the model of Government in which people participate will improve their lives and make them move towards their goals of life and still be able to meet the needs of the people as possible. People can negotiate benefits with representatives, while other governments are brutal. A Representative system can create happiness for people because people can self-protecting. Mill emphasizes that people must be involved in Government because it is the only way to bring the greatest happiness to the greatest number. [4, p. 156]

As mentioned above, the authors found that Mill proposed a compromise between Plato and Rousseau's radical idea: the people who believe in people and those who believe in them. Mill stressed that people should participate in Government at the representative selection level because people can choose what they want and bring happiness. Also, if the rulers who represent the people ignore or do not meet the people's needs, they can choose a new representative who is ready to meet the people's needs.

\section{Richard Sylvan's answer was, "There is no need for a ruler; people can take themselves.}

In this last answer, the authors propose an idea that dismantles the mainstream answer - the anarchist ideology, particularly Richard Sylvan. He explains that the academic circle of political philosophers agree that anarchism is a thought that requires the abolition of all states. Besides, anarchists are considered idealists. Anarchism is an ideology that arises for the resistance of modern states. Even more, than this idea appeared in previous philosophies. (Stoicism and Taoism) Furthermore, it appears in writings of the late $18^{\text {th }}$ century, especially the French Revolution.

Initially, the term "Anarchist" condemns those who reject the law and those who crave chaos. It was used again during the British civil war and the French revolution. Most political parties criticize the left in the political-ideological spectrum. It was then officially used in the works of PierreJoseph Proudhon on What is Property? (1840). He said he was an anarchist because he believed in a political organization based on authority. It should be replaced by a social and economic organization following non-compulsory and voluntary agreements. Then this ideology spread wildly, especially during the 1960s [10, p. 257] .Philosophically, anarchism is either a theory, a principle, or a practice. The dictionary means There are three essential structures in politics: authority, coercion, and the general use of both. 
The principle of opposition to all states' existence is not a matter of meaning; the authors explain that it is critical to the prevailing state system's nature. It is not easy to choose anarchy; for example, when the traffic police stopped working, traffic continued as before, presumably an interlude to the surrounding power structures. The end of Marxist was a highly productive authoritarian dictator. This hypothesis simulates the error that anarchism is far from political practice in modern, complex states. The issue of state monopoly is brutal coercion of power, so anarchy is used to solve such problems to end institutions and create new ones [10, p. 260]. Besides, the English language with the word "Anarchy" focuses on the damaging, mescaline, disorderly, disobediently of leaders who have been influenced by the Greek era. Therefore, the first meaning contradicts the present meaning. Anarchy gives absolute freedom to the individual, But the vital question is, if there were no heads of Government, leaders, and central, what would be the political structure?

Anarchists propose that response is not necessary for a mathematical structure but included in the definition of anarchic modern goals, i.e., an organization can accept an organization without coercion of power. Moreover, it must be voluntary and cooperative. Anarchists have many theories in which anarchy is merely a structural theory that highlights the rejection of authority, consistent with the principle of denial of power and the state's intimidation. Simultaneously, trying to limit anarchism to specific forms, blocking the state's mandate to lead to independence is generally performed, first, with society's good, which must be ethical. Second, it caused self-government to lead to anarchy. However, these proposals have been contested with differences, intimidation, and instrumental coercion. These are generally recognized as ethical undesirable. The core of anarchism is anti-statism, anti-clericalism, utopianism, and free trade.

The debate against that state anarchists criticizes the state as a tool and a privileged means to create wealth for elites linked to political and social power, and that society cannot match with the state. However, the state was replaced or even dissolved. A state that is undesirable and does not take seriously the bad. In particular, the state is still a cause of war, excessive support for the military budget, overproduction, and production of weapons for export, especially nuclear weapons, and without a state, would not be a nuclear war that would damage the world [10, p. 266].

The authors see anarchism as a critical tool, as the concept of the building. The anarchists question the theory of the birth of the mainstream state influenced by the community contract theory because the state is not born in the natural state or the covenant path and agrees with the liberals that the state has to have the least power and function of the stable and only take care of some organization. This argument found that the patriarchal state oppressed many people with unjust political activities, and anarchy was also against the idea of divinity, and the argument against god led to the core of anarchism against the church. Although political scientists view these paths as absurd, they discussed replacing state operations and functions outside of the mainstream political science conference through preparation and options to establish in the territory designated by the state. Nozick's Anarchy, State, and Utopia, whose replacement was successful, created a utopian to face the state. Other main routes lead to confrontation, and revolutionary paths route through direct action to state activities and practices [11]. The use of movement and technical anarchism in political action, such as environmental and peace movements, is the underlying anarchist ideology in society, and they hope for the people's popularity in anarchy to achieve great goals in the future. In the $19^{\text {th }}$ century, Robert Owen's work in England and Charles Fourier, Henri Saint-Simon, and Étienne Cabet in France, known as utopian socialists, created a better future establishment of a small experimental community. On the other hand, Karl Marx and Friedrich Engels, and others argue that such an approach does not solve industrial society's problems and that the "Utopian" symbol has an unrealistic and innocent meaning. Later, both dissident theorists and advocates of utopianism debated the desire to describe society as a means of significant social change. Christian religious thinkers were deeply divided with utopianism. Is seeing a better life on earth unorthodox or normal to Christian thinking? Since the fall of communism in Eastern Europe and the former Soviet Union. Many theorists have argued that utopianism is over and is still being intentionally written and formed by communities hoping that better life is possible [12].

Finally, when heading towards utopia, rulers are no longer needed because anarchists believe that humanity is useful from birth or that humanity is born with good. Humans have the potential to create good social interactions with one another and cooperate. Reconciliation is a process that occurs naturally in human society. Moreover, it is the order of nature that tends to cooperate and depend on harmony, aiming for everyone to survive simultaneously. If anyone is not ready, they will make it available for the less fortunate to survive together. Unlike competitive liberals, they ignore the people behind them. Tyrant rulers not doing it for the public good must be removed. Hence the belief that the assassination of a leader is righteous and just in itself. Failure to do so for the public or the public is to exploit and oppress, whether by the rulers themselves or by politicians, businesspeople, and bureaucrats against the proletariat. Anarchists see the daily violence of society as a mirror of the truth from the creators of violence. Therefore, terrorism in an anarchist perspective is Revolutionary justice under the eyeball-to-eyeball concept and can also reduce a ruler's moral or the ruling class. To make the ruling class lose power, privilege, and show weakness in the rulers defenselessness. It can also elevate the political bureaucracy and motivate the public to move on to the revolutionary path to create a genuinely utopian society.

\section{Conclusion}

The authors offer various answers from political scientists to answer the question: "Who should rule?". To seek out a wide variety of answers and to be able to consider and use them in different contexts or situations. In my opinion, that every answer is essential to current and future forms of governance. That is to say, the ideas of everyone referred to build quality in the field of political education and political science, including their implementation or application to suit each social context. Plato's concept was adopted in many 
city-states during ancient Greece. While not all of them can be used, all children's involvement with multiple studies and tests is done. They are found in various city-states, especially Sparta. However, the ban on property and family possession is far from feasible because no one would be willing to study until the age of 50 but nothing of his own. While Rousseau's proposal was idealistic because in the real world, each country's population is millions of people, and not everyone can legislate themselves. However, Rousseau emphasized that the proposal reflected the freedom and equality of all citizens. Even if it applies to others, the majority of votes must be approved. Nevertheless, this Rousseau concept has produced some exciting results; the French Revolution events in 1789 that appear more than Rousseau's idea is one of the revolutionary scrolls.

Also, Aristotle's proposal combines all forms of Government and can describe a separate condensed form of Government based on the number of people exercising power and the exercise of power. He supports the Polity that the authors see as the dominant majority of the middle class. In other words, when the middle class has political power, of course, policy issuance offers the needs of the middle class, but if we look at it, we will find that the policies that offer the middle class are not extreme. However, these three answers were disputed by Mill. He argues that only the people's chosen rulers can bring happiness to the largest number of people according to the concept of happiness because other forms of governing are not as useful as agents. However, the authors take the work of Sylvan and other anarchists to explain a different answer: There is no need for a ruler, people can take themselves. Because anarchists see that human beings are born with virtue, the state creates inequality, exploits humankind, and causes war.

Finally, the authors believe that the concept of social contract and happiness under Mill's representative system is most desirable for parents today because they can change their parents at any time or according to the general will agenda. Furthermore, able to combine ideologies, not necessarily liberal democracy. In modern times, a representative system can be a mixed constitution that incorporates other forms to adapt to various political and social contexts, such as a social-democratic regime. Although the representative system cannot guarantee the rulers' outcome in the public interest, the authors think it is the only system capable of recalling sovereignty to the people. To select a new ruler, ready to create happiness for the largest number of people.

\section{References}

[1] M. H. Hansen, "Athens as a City-State and as Democracy," in The Athennian Democracy in the Age of Demothenses: Structure, Principle and Idealogy, Norman, University of Oklahoma Press, 1999.

[2] D. Stockton, The Classical Athenian Democracy, Oxford: Oxford University Press, 1990.
[3] R. Colson, The Politics Book, London: Doriling Kindersley Limited, 2013.

[4] S. Suphaphol, Introduction to Political Philosophy, Chiangmai: Chiangmai university, 2015.

[5] J. Wolff, An Introduction to Political Philosophy, 3 ed., Oxford: Oxford University Press, 2016.

[6] J. J. Rousseau, The Social contract and Discourse, London: Everyman, 1993.

[7] R. Mckeon, "Politics," in The Basic work of Aristotle, New York, The Modern Library, 2001.

[8] J. S. Mill, "On Liberty / John Stuart Mill," D. Bromwich and G. Kateb, Eds., New York, Rethinking the Western Tradition, 2003.

[9] L. Strauss and J. Cropsey, History of political philosophy, vol. 3, Bangkok: Chobfi, 2015.

[10] R. Sylvan, "Anarchism," in A companion to contemporary political philosophy, 2nd ed., R. E. Goodin and P. Pettit, Eds., Hong Kong, Blackwell Publishing Ltd, 2007.

[11] R. Nozick, Anarchy, State, and Utopia, Oxford: Basic Books, 1974.

[12] L. T. Sargent, "Utopianism," in The Routledge Encyclopedia of Philosophy, Taylor and Francis, 1998. 